\title{
Serum Dickkopf-1 as A Biomarker for The Diagnosis and Prognosis of Hepatocellular Carcinoma \\ Khalid Mahmoud Abd El-Hafeez ${ }^{1}$, Mahmoud Bastawy Ismael ${ }^{2}$, Ahmed Abd-Elaleem Abuo-Elhasan ${ }^{1}$, Amir Abd El-Aziz Mohammed Al-Damaty ${ }^{1}$ \\ Departments of ${ }^{1}$ Tropical Medicine and ${ }^{2}$ Clinical Pathology, Faculty of Medicine, \\ Al-Azhar University-Cairo, Egypt \\ Corresponding author: Amir Abd El-Aziz Mohammed Al-Damaty, Email: mero4u2012@yahoo.com
}

\begin{abstract}
Background: Hepatocellular carcinoma is one of the commonest cancers in world. It is one of the major health problems and its incidence is increasing. The main routinely used parameter for diagnosis of HCC is AFP, also it can be elevated in the liver cirrhosis. It represents a liver cell specific, not a tumor specific marker, for these reasons, we suggest use AFP as a supplementary marker for HCC diagnosis. So, identification of a sensitive biomarker to improve early diagnosis of $\mathrm{HCC}$ is in need.

Aim of the work: this study was aimed to evaluate the clinical significance of serum Dickkopf-1 (DKK1) as a diagnostic and prognostic marker in hepatocellular carcinoma. Patients and Methods: in this study 100 subjects were included and divided into 3 groups, Group I: included 50 patients with HCC, and divided into 2 subgroups according to Barcelona Clinic Liver Cancer (BCLC) into early HCC (24 patients) and late HCC (18 patients). Group II: included 25 patients with liver cirrhosis. Group III: included 25 healthy subjects (control). Clinical assessment, routine laboratory evaluation, CT scan and measurements of serum alpha-fetoprotein (AFP) and DKK1 were performed to all patients and repeated to group I patients 1 month after treatment.

Results: the current study showed that Serum DKK1 was significantly elevated in HCC group compared to liver cirrhosis and healthy control groups, with increased level in late than early stage. The optimum cut off values of DKK1 for diagnosis of HCC was $1.92 \mathrm{ng} / \mathrm{mL}$ (AUC 0.926, sensitivity $88 \%$ and specificity 83\%). While the optimum cut off value for AFP was $102 \mathrm{ng} / \mathrm{mL}$ (AUC $0.904,71 \%$ sensitivity and $84 \%$ specificity). Testing of both serum DKK1 and AFP increased the diagnostic accuracy for HCC (AUC 0.964, sensitivity 91\%, and specificity 90\%). Serum DKK1 level significantly decreases after HCC treatment with radio-frequency ablation.

Conclusion: It could be concluded that Testing of both serum DKK1 and AFP significantly increased the diagnostic accuracy for HCC. Meanwhile, DKK1 can be used alone for diagnosis of HCC even in HCC with inconclusive AFP. Serum DKK1 might be a potential diagnostic and prognostic marker for HCC.
\end{abstract}

Keywords: HCC patients, DKK1, AFP.

\section{INTRODUCTION}

Hepatocellular carcinoma is the sixth most common malignant disease, and the third leading cause of cancer related death worldwide. HCC is prevalent in Asia and Africa, but it raises recently in the Western world due to an increase in hepatitis $\mathrm{C}$ virus infection [1]. In Egypt, Cancer liver forms $11.75 \%$ of the malignancies of all GIT organs and $1.6 \%$ of the total malignancies ${ }^{[2]}$.

Risk factors for $\mathrm{HCC}$ includes chronic hepatitis $\mathrm{B}$ virus and chronic hepatitis $\mathrm{C}$ infections, cirrhosis, chronic alcohol abuse, aflatoxin ingestion, non-alcoholic steatohepatitis (NASH) and metabolic liver diseases ${ }^{[3]}$.

Both HCV and HBV infections are most common risk factors for HCC among the Egyptian patients. 10\%-20\% of the general Egyptian population are HCV infected ${ }^{[4]}$.

$80 \%-90 \%$ of patients with HCC have underlying cirrhosis and the remaining $10 \%-20 \%$ of the cases develop HCC without cirrhosis ${ }^{[5]}$.

HCC is disease with fast infiltrating growth and very poor prognosis ${ }^{[6]}$. The commonly used screening method for liver cancer are ultrasound examination (US) of the liver and determination of

serum AFP levels ${ }^{[7]}$. Abdominal ultrasound is better, simple and easy method for the detection of HCC but it is an operator dependent and many focal lesions could be missed ${ }^{[8]}$.

AFP has approximately $60 \%$ specificity and $40 \%$ sensitivity for diagnosis of HCC, since minor elevations are common in the patients with chronic liver diseases, cirrhosis, germ cell tumor and in pregnancies ${ }^{[9]}$.

So, it is necessary to find specific and sensitive marker for early diagnosis of $\mathrm{HCC}$, and for monitoring of the treatment response.

Dickkopf-1 (DKK1) is secretory protein which was first identified in 1998. DKK1 is an inhibitor of Wnt/ $\beta$-catenin signaling pathway and a downstream target for $\beta$-catenin ${ }^{[10]}$.

The Wnt/ $\beta$-catenin signaling pathway plays the main role in the development of both normal liver and hepato-carcinogenesis ${ }^{[11]}$.

It is hardly expressed in the normal human adult tissue except in placenta and embryonic tissue ${ }^{[12]}$. 
DKK1 is up-regulated in various cancers including lung, breast, ovarian, prostatic cancers and $\mathrm{HCC}^{[13]}$.

\section{AIM OF THE WORK}

This study was aimed to evaluate the clinical significance of serum Dickkopf-1 (DKK1) as a diagnostic and prognostic marker in hepatocellular carcinoma.

\section{PATIENTS and METHODS}

This cross-sectional study included a total of 75 patients with HCC and liver cirrhosis and 25 agematched normal control individuals attending at AlAzhar University Hospitals. Approval of the ethical committee and a written informed consent from all the subjects were obtained. This study was conducted between May 2016 and September 2018.

The 100 subjects included in this study were divided into 3 groups:

Group I: included 50 patients with HCC, and divided into 2 subgroups according to BCLC into early HCC (24 patients) and late HCC (18 patients).

Group II: included 25 patients with liver cirrhosis. Group III: included 25 healthy subjects (control). Clinical assessment, routine laboratory evaluation, CT studies and measurement of serum alpha-fetoprotein (AFP) and DKK1 were performed to all patients and repeated to group I patients 1 month after treatment.

\section{RESULTS}

Serum DKK1 and AFP were significantly elevated in group I compared to group II and III $(\mathrm{P}<0.01)$ (Table 1), Mean serum DKK1 level in group I, II and III was $2.41 \pm 1.12,0.36 \pm 0.05$ and $0.31 \pm$ $0.02 \mathrm{ng} / \mathrm{ml}$ respectively, and Mean serum AFP level in group I, II and III was $657 \pm 433,36 \pm 18$ and $6 \pm 3$ $\mathrm{ng} / \mathrm{ml}$ respectively (Figure 1,2).
Comparison between Group II and III as regard serum DKK1 and AFP levels showed that there is significant difference as regard serum AFP $(\mathrm{P}<0.01)$, but no significant difference as regard to serum DKK1 ( $>>0.1)$ (Table 2). Comparison between (Early HCC; BCLC 0,A) and (Late HCC; BCLC B,C) as regard serum DKK1 and AFP levels showed that there is statistically significant difference as regard serum DKK1 and AFP $(\mathrm{P}<0.01)$ (Table 3).

Comparison between Very Early HCC (BCLC 0) and Group II as regard serum DKK1 and AFP levels showed that there is statistically significant difference as regard serum DKK1 $(\mathrm{P}<0.01)$ (Table 4), But no significant difference as regard serum AFP (P>0.1).

Comparison between before and after treatment with RF (curative) as regard serum DKK1 and AFP levels showed that there is statistically significant difference as regard serum DKK1 $(\mathrm{P}<0.05)$, But no significant difference as regard serum AFP $(\mathrm{P}>0.1)$. Comparison between before and after treatment with TACE (palliative) as regard serum DKK1 and AFP levels showed that There is no statistically significant difference as regard serum DKK1 and AFP $(\mathrm{P}>0.1)$.

The diagnostic performance of serum AFP and serum DKK1 when individually used for the discriminating of Group I from Group II and Group III, showed that the optimum diagnostic cut off value for DKK1 was $1,92 \mathrm{ng} / \mathrm{mL}$ with $88 \%$ sensitivity and $83 \%$ specificity while, the cut off value for AFP was $102 \mathrm{ng} / \mathrm{mL}$ with $71 \%$ sensitivity and $84 \%$ specificity.

Combined use of both serum DKK1 and AFP increased the diagnostic accuracy for HCC compared with either of test alone (AUC 0.964, sensitivity 91\%, and specificity 90\%) (Table 5,6 and Figure 3).

Table (1): Statistical comparison between study groups as regard serum DKK1 and AFP levels

\begin{tabular}{||c|c|c|c||c|c|c||}
\hline & $\begin{array}{c}\text { Group I } \\
\text { (HCC) } \\
{[\mathbf{n = 5 0 ]}}\end{array}$ & $\begin{array}{c}\text { Group II } \\
\text { (Liver } \\
\text { Cirrhosis) } \\
{[\mathbf{n = 2 5}}\end{array}$ & $\begin{array}{c}\mathbf{P} \\
\text { value }\end{array}$ & $\begin{array}{c}\text { Group I } \\
\text { (HCC) } \\
{[\mathbf{n = 5 0}}\end{array}$ & $\begin{array}{c}\text { Group } \\
\text { III } \\
\text { (Control) } \\
{[\mathbf{n = 2 5}]}\end{array}$ & $\begin{array}{c}\text { P } \\
\text { value }\end{array}$ \\
\hline \hline DKK1(ng/ml) & $\begin{array}{c}2.41 \pm \\
0.12\end{array}$ & $\begin{array}{c}0.36 \pm \\
0.05\end{array}$ & $<\mathbf{0 . 0 1 *}$ & $\begin{array}{c}2.41 \pm \\
0.12\end{array}$ & $\begin{array}{c}0.31 \pm \\
0.02\end{array}$ & $<\mathbf{0 . 0 1 *}$ \\
\hline AFP $(\mathbf{n g} / \mathbf{m l})$ & $\begin{array}{c}657 \pm \\
133\end{array}$ & $36 \pm 8$ & $<\mathbf{0 . 0 1 *}$ & $657 \pm 33$ & $6 \pm 1$ & $<\mathbf{0 . 0 1 *}$ \\
\hline
\end{tabular}

Table (2): Statistical comparison between Group II (liver cirrhosis) and Group III (control) as regard serum DKK1 and AFP levels

\begin{tabular}{|c|c|c|c|}
\hline \hline & $\begin{array}{c}\text { Group II } \\
\text { (Liver Cirrhosis) } \\
{[\mathbf{n = 2 5}]}\end{array}$ & $\begin{array}{c}\text { Group III } \\
\text { (Control) } \\
{[\mathbf{n = 2 5}]}\end{array}$ & P value \\
\hline \hline DKK1 $(\mathbf{n g} / \mathbf{m l})$ & $0.36 \pm 0.05$ & $0.31 \pm 0.02$ & $>0.1$ \\
\hline AFP $(\mathbf{n g} / \mathbf{m l})$ & $36 \pm 8$ & $6 \pm 1$ & $<\mathbf{0 . 0 1 *}$ \\
\hline
\end{tabular}


Table (3): Statistical comparison between subgroup IA (Early HCC; BCLC 0,A) and subgroup IB (Late HCC; BCLC B,C) as regard serum DKK1 and AFP levels

\begin{tabular}{|c|c|c|c||}
\hline & $\begin{array}{c}\text { Subgroup IA } \\
\text { Early HCC [n=24] }\end{array}$ & $\begin{array}{c}\text { Subgroup IB } \\
\text { Late HCC [n=18] }\end{array}$ & P value \\
\hline \hline DKK1 (ng/ml) & $1.72 \pm 0.28$ & $3.61 \pm 0.34$ & $<\mathbf{0 . 0 1 *}$ \\
\hline AFP $(\mathbf{n g} / \mathbf{m l})$ & $76 \pm 3$ & $866 \pm 33$ & $<\mathbf{0 . 0 1 *}$ \\
\hline
\end{tabular}

g

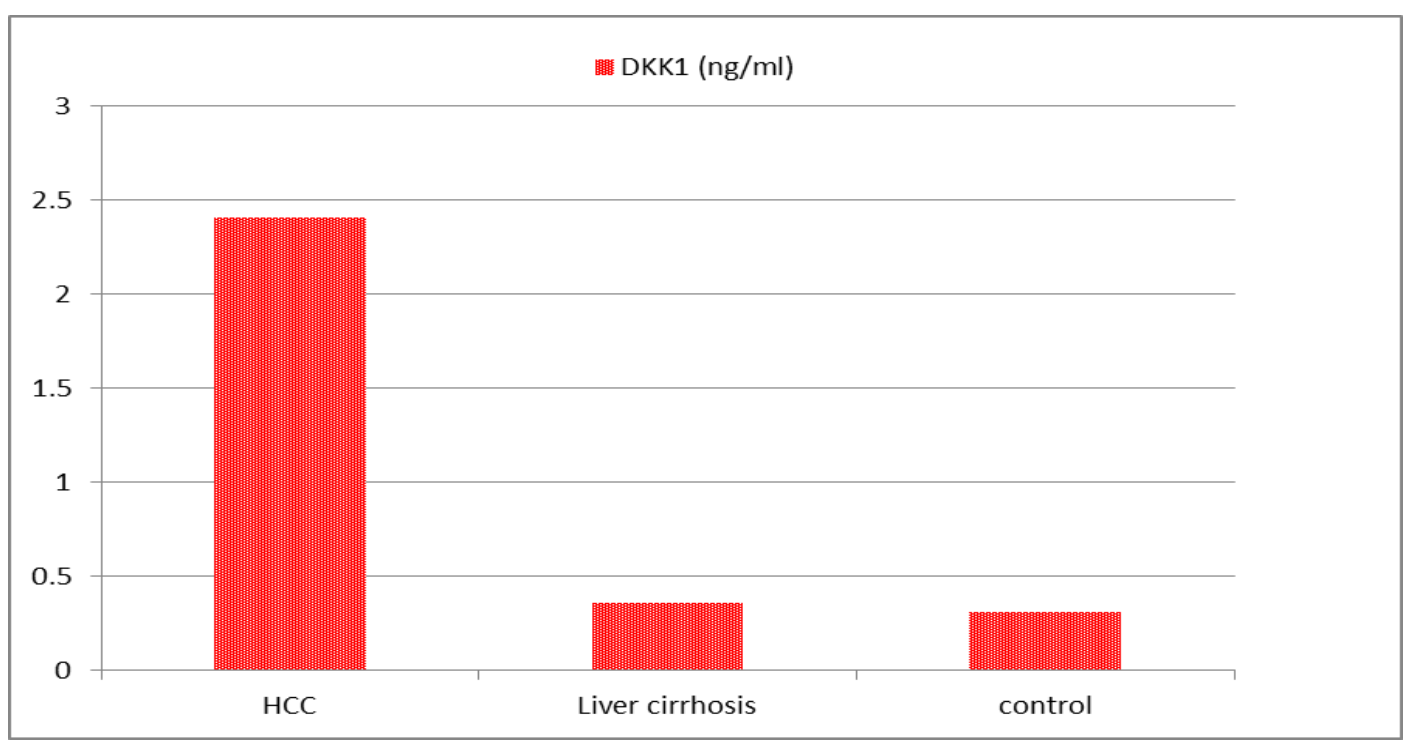

Figure (1): Mean serum DKK1 levels in HCC, liver cirrhosis and healthy control groups Figure (2): Mean serum AFP levels in HCC, liver cirrhosis and healthy control groups

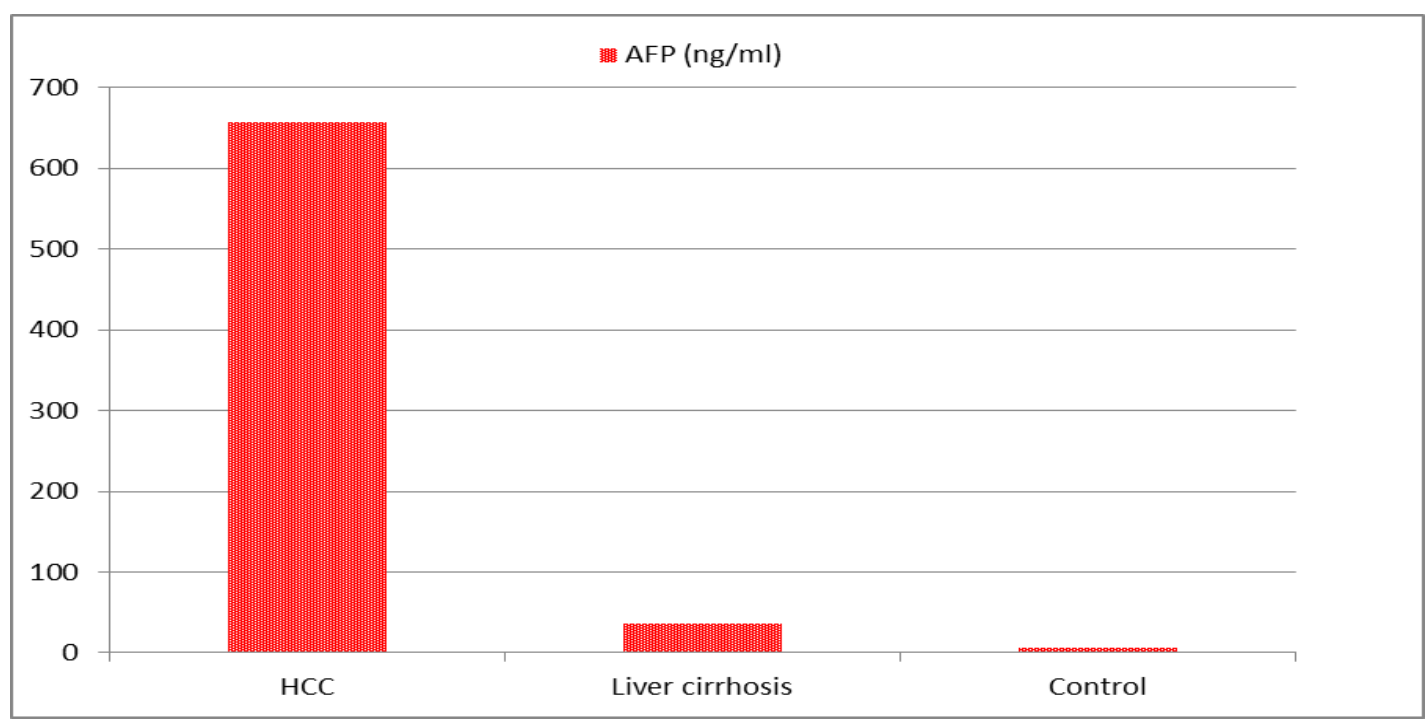

Table (4): Statistical comparison between Very Early HCC (BCLC 0; single HFL $<2 \mathrm{~cm}$ ) and Group II (liver cirrhosis) as regard serum DKK1 and AFP levels

\begin{tabular}{|c|c|c|c|}
\hline & $\begin{array}{c}\text { Very Early HCC } \\
\text { (BCLC 0) [n=6] }\end{array}$ & $\begin{array}{c}\text { Group II } \\
\text { (Liver Cirrhosis) [n=25] }\end{array}$ & P value \\
\hline \hline DKK1 (ng/ml) & $1.46 \pm 0.12$ & $0.36 \pm 0.05$ & $<\mathbf{0 . 0 1 *}$ \\
\hline AFP $(\mathbf{n g} / \mathbf{m l})$ & $42 \pm 4$ & $36 \pm 8$ & $>0.1$ \\
\hline
\end{tabular}


Table (5): Diagnostic performance of serum DKK1 and serum AFP when individually used for discriminating Group I (HCC) from Group II (Liver Cirrhosis) and Group III (Control).

\begin{tabular}{|c|r|c|c|c|c|c|}
\hline & $\begin{array}{r}\text { AUC } \\
(95 \% \text { CI })\end{array}$ & $\begin{array}{c}\text { ROC } \\
\text { Cutoff }\end{array}$ & $\begin{array}{c}\text { Diagnostic } \\
\text { Sensitivity (\%) }\end{array}$ & $\begin{array}{c}\text { Diagnostic } \\
\text { Specificity (\%) }\end{array}$ & PPV (\%) & NPV (\%) \\
\hline AFP (ng/mL) & 0.904 & 102 & $71 \%$ & $84 \%$ & $82 \%$ & $66 \%$ \\
\hline DKK1 (ng/mL) & 0.926 & 1,92 & $88 \%$ & $83 \%$ & $86 \%$ & $78 \%$ \\
\hline
\end{tabular}

Table (6): Diagnostic performance of combined use of both serum DKK1 and serum AFP for Discriminating Group I (HCC) from Group II (Liver Cirrhosis) and Group III (Control).

\begin{tabular}{|r|c|c|c|c|c|}
\hline & $\begin{array}{c}\text { AUC } \\
\mathbf{9 5 \%} \text { CI) }\end{array}$ & $\begin{array}{c}\text { Diagnostic } \\
\text { Sensitivity (\%) }\end{array}$ & $\begin{array}{c}\text { Diagnostic } \\
\text { Specificity (\%) }\end{array}$ & PPV (\%) & NPV (\%) \\
\hline $\begin{array}{c}\text { Combined } \\
\text { AFP+DKK1 }\end{array}$ & 0.964 & $91 \%$ & $90 \%$ & $92 \%$ & $88 \%$ \\
\hline
\end{tabular}

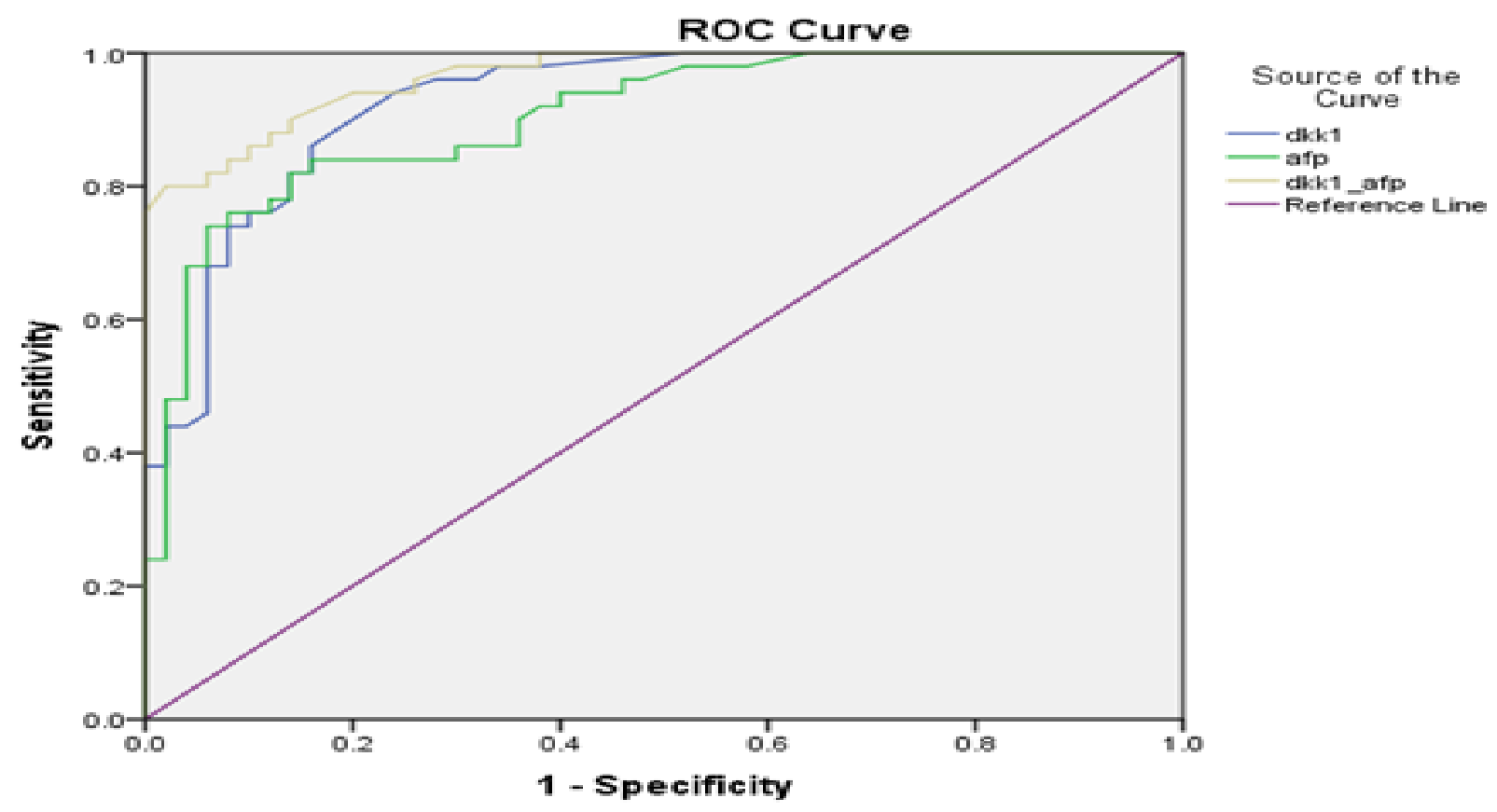

Figure (3): Multi-ROC curve analysis showing the diagnostic performance of the combined use of DKK1 $(\mathrm{ng} / \mathrm{mL})$ and AFP $(\mathrm{ng} / \mathrm{mL})$ in discriminating Group I (HCC) from Group II (Liver Cirrhosis) and Group III (Control), compared to their individual ROC curves.

\section{DISCUSSION}

Hepatocellular carcinoma is one of the most common primary malignancies of the liver, forming about $85-90 \%$ of the all primary liver cancers ${ }^{[14]}$. $80 \%-90 \%$ of patients with liver cirrhosis will progress to $\mathrm{HCC}, \mathrm{HCV}$ infection was present in $27 \%-70 \%$ and $\mathrm{HBV}$ infection in $12 \%-50 \%$ of cases ${ }^{[15]}$. Early detection of HCC gives the opportunity for curative treatment which can prolong survival, Despite the vigorous trials to screen for early $\mathrm{HCC}$ by using serum AFP and abdominal ultrasound, early HCC is asymptomatic and the most cases are presented late at which the surgical treatment are not valuable ${ }^{[16]} .30$ $47 \%$ of patients with HCC are AFP negative and abdominal ultrasound used in the detection for HCC is suboptimal ${ }^{[17]}$. As a result, the widespread use of serum AFP and ultrasound for surveillance of HCC has been questioned.

The Wnt/ $\beta$-catenin signaling pathway plays an important role in development of both normal liver

and hepato-carcinogenesis ${ }^{[18]}$. The DKK family are a secreted glycoproteins and have ability in regulating Wnt/ $\beta$-catenin. DKK-1 is the most studied member of DKK family, it is rarely expressed in normal tissue except in placental and embryonic tissues ${ }^{[19]}$. Shen et al. ${ }^{[20]}$ suggest that, DKK1 may be potential marker in the diagnosis of many types of cancers, and elevated expression of DKK1 is associated with development of HCC. Also, they reported the diagnostic accuracy of DKK1 as serum marker for HCC diagnosis in large-scale, multicenter study. The study documented that, serum DKK1 has a high sensitivity and 
specificity in the diagnosing of $\mathrm{HCC}$, especially early stages and HCC cases with normal $\alpha$-fetoprotein (AFP). They also demonstrated that the combination of both serum $\alpha$-fetoprotein with DKK1 could further improve the diagnostic accuracy.

Our study revealed higher incidence of HCC in males than in females (80\%and 20\% respectively), male:female ratio was $4: 1$,in which was also published by El-Serag and Rudolph ${ }^{[14]}$.serum DKK1 it was significantly higher in group I compared with group II and group III ( $<<0.01)$, But there was no significant difference in group II compared with group III ( $>0.1)$, These results are in agreement with Shen et al. ${ }^{[20]}$, who found that levels of DKK1 in serum were significantly higher in patients with HCC than in liver cirrhosis and healthy control groups. They found also that DKK1 were not significantly higher in liver cirrhosis patients in comparing to healthy control group.

In our study, serum DKK1 and AFP were significantly higher in subgroup IB (late HCC) compared with subgroup IA (early HCC) $(\mathrm{p}<0.01)$, so DKK1 has a prognostic value. Our results are in agreement with Hoda $\boldsymbol{e t}$ al. ${ }^{[21]}$ who assessed serum DKK1 according to BCLC staging of $\mathrm{HCC}$, they found a significantly increased serum DKK1 level in patients with BCLC $(\mathrm{C}, \mathrm{D})$ than BCLC $(\mathrm{A}, \mathrm{B})$ stage. Another study by $\mathbf{Y u}$ et al. ${ }^{[22]}$ found that Dkk1 was significantly elevated in multi-nodular HCC (multiple lesions) with high metastatic potential comparing to solitary HCC. In the present study, serum DKK1 was significantly higher in very early HCC (single HFL $<2 \mathrm{~cm})$ group comparing with group II $(\mathrm{p}<0.01)$. But there was no significant differences in both groups as regard serum AFP ( $>0.1)$. These results agreed with Hoda et al. ${ }^{[21]}$ who found significant elevations of serum DKK1 levels in cases with HCC less than $2 \mathrm{~cm}$ in diameter (single HFL) when comparing to healthy control, and the levels was increased significantly to be higher among lesions $>5 \mathrm{~cm}$ comparing to smaller one $(<2 \mathrm{~cm})$. As regard serum DKK1 and AFP before and after curative treatment with $\mathrm{RF}$, there were significant differences between both groups as regard DKK1 $(\mathrm{p}<0.05)$, But no significant difference between both groups as regard AFP ( $p>0.1)$. On the other hand, serum DKK1 and AFP before and after palliative treatment (TACE), there were no significant difference in both groups $(\mathrm{p}>0.1)$. Our results are in agreements with Sharaf et al. ${ }^{[23]}$ who found that there were significant differences between the patients treated with either radiofrequency ablation (RF) or ethanol injection (EI) as regards AFP and DKK1, there was decrease in the mean level of both serum markers after treatment $(\mathrm{p}<0.001)$.

Assessment of diagnostic performance of both serum DKK1 and AFP when used in discriminating Group I (HCC) from Group II (Liver Cirrhosis) and Group III (Control), revealed a better diagnostic performance of DKK1 (AUC 0.926) compared to AFP (AUC 0.904).The best ROC cut-off for DKK1 was $1,92 \mathrm{ng} / \mathrm{mL}$, this had a diagnostic sensitivity of $88 \%$, specificity $83 \%$, positive predictive value $86 \%$, negative predictive value $78 \%$. The best ROC cut-off for AFP was $102 \mathrm{ng} / \mathrm{mL}$, this had a diagnostic sensitivity of $71 \%$, specificity $84 \%$, positive predictive value $82 \%$, negative predictive value $66 \%$. Our results are in agreement with Ge $\boldsymbol{e t}$ al. ${ }^{[24]}$ who reported the better diagnostic performance in the case of DKK1 (AUC 0.889) compared to AFP (AUC 0.831).

Their best cut-off for serum DKK1 was 1,31 $\mathrm{ng} / \mathrm{mL}$, this had diagnostic sensitivity of $79.8 \%$ and specificity $89.4 \%$, and the best ROC cut-off for AFP was $6.8 \mathrm{ng} / \mathrm{mL}$, this had a diagnostic specificity $88.0 \%$ and sensitivity of $71.9 \%$. Assessment of diagnostic performance of combined use of both serum DKK1 and AFP in discriminating Group I (HCC) from Group II (Liver Cirrhosis) and Group III (Control), revealed a better diagnostic performance than that of DKK1 or AFP alone with (AUC 0.964), sensitivity was $91 \%$, specificity $90 \%$, positive predictive value $92 \%$, negative predictive value $88 \%$. Our results are agree with Ge $\boldsymbol{e}$ al. ${ }^{[24]}$ who reported a better diagnostic performance of the combined use of both markers as evidenced by the increased in the AUC to reach 0.931 vs 0.831 for AFP and 0.889 for DKK1 when individually used, this had a diagnostic specificity of $87.7 \%$, and sensitivity of $88.8 \%$, Also our results are in accordance with Shen et al. ${ }^{[20]}$ who reported that the combination of both AFP and DKK1 could further improve the diagnostic accuracy of hepatocellular carcinoma.

Concerning our evaluation of the diagnostic utility of serum DKK1 and serum AFP in discriminating early $\mathrm{HCC}$ (BCLC 0, A) from late HCC (BCLC B, C), our results revealed a good discriminating ability for DKK1 where the (AUC was 0.964). The best cut-off was $2,85 \mathrm{ng} / \mathrm{mL}$ with diagnostic sensitivity of $93 \%$, specificity $90 \%$, positive predictive value $91 \%$, negative predictive value $85 \%$. Concerning serum AFP, this showed a lower performance (AUC was 0.942). The best cutoff was $477 \mathrm{ng} / \mathrm{mL}$ with a diagnostic sensitivity of $82 \%$, specificity $91 \%$, positive predictive value $87 \%$, negative predictive value $83 \%$. These results agreed with Kim et al. ${ }^{[25]}$ who found that serum DKK1 is efficient in the discrimination of early from late HCC.

\section{CONCLUSION}

This study showed that serum DKK1 may serve as good diagnostic biomarker for the HCC diagnosis particularly at early stages, also DKK1 alone or in combination with AFP can significantly 
improve the diagnostic accuracy of early HCC with sensitivity, specificity and accuracy higher than of AFP alone. DKK1 may serve as good prognostic biomarkers for HCC which evidenced by statistically significant differences between its level in early and late stages of HCC. DKK1 could be a promising marker for prediction of complete and partial response to treatment either curative (RF) or palliative (TACE).

\section{REFERENCES}

1. Altekruse SF, McGlynn KA and Reichman ME (2009): Hepatocellular carcinoma incidence, mortality, and survival trends in the United States from 1975 to 2005. J Clin Oncol., 27: 1485-1491.

2. Mokhtar N, Gouda I and Adel I (2007): Cancer Pathology registry (2003-2004) and time trend analysis. www.scirp/(s(vt3fa45qm1ean45vvffcz55))/reference/Referen cesPapers.aspx?.

3. Severi T, van Malenstein $H$, Verslype $C$ et al. (2010): Tumor initiation and progression in hepatocellular carcinoma: risk factors, classification, and therapeutic targets. Acta Pharmacol Sin. ,31:1409-1420.

4. Habib M, Mohamed MK, Abdel Aziz F et al. (2001): Hepatitis C Virus in a community in the Nile Delta: risk factors for Seropositivity. Hepatology, 33 (1): 248-53.

5. Nguyen VT, Law MG and Dore GJ (2009): Hepatitis B-related hepatocellular carcinoma: epidemiological characteristics and disease burden. J Viral Hepat., 16:453463.

6. Yao DF, Dong ZZ and Yao M (2007): Specific molecular markers in hepatocellular carcinoma. Hepatobiliary Pancreat Dis Int., 6: 241-247.

7. Daniele B, Bencivenga A, Megna AS et al. (2004): $\alpha$ fetoprotein and ultrasonography screening for hepatocellular carcinoma. Gastroenterol., 127: S108-112.

8. Sheu JC, Sung JL, Chen DS et al. (1985): Early detection of hepatocellular carcinoma by real-time ultrasonography. A prospective study. Cancer, 56: 660666.

9. Nguyen MH, Garcia RT, Simpson PW et al. (2002): Racial differences in effectiveness of alpha-fetoprotein for diagnosis of hepatocellular carcinoma in hepatitis $\mathrm{C}$ virus cirrhosis. Hepatology, 36, 410-417.

10. Fatima S, Lee NP and Luk JM (2011): Dickkopfs and $\mathrm{Wnt} / \beta$-catenin signalling in liver cancer. World $\mathbf{J}$ Clin Oncol., 2:311-325.

11. MacDonald BT, Tamai $K$ and He $X$ (2009): Wnt/ $\beta$ catenin signaling: components, mechanisms, and diseases. Dev Cell. 17: 9-26.
12. Fedi P, Bafico A, Soria AN et al. (1999): Isolation and biochemical characterization of the human Dkk-1 homologue, a novel inhibitor of mammalian Wnt signaling. J Biol Chem., 274: 19465-19472.

13. Hall CL, Daignault SD, Shah RB et al. (2008): Dickkopf-1 expression increases early in prostate cancer development and decreases during progression from primary tumor to metastasis. Prostate, 68: 1396-1404.

14. El-Serag HB and Rudolph KL (2007): Hepatocellular carcinoma: epidemiology and molecular carcinogenesis. Gastroenterology, 132:2557-2576.

15. Kanwal F, Hoang T, Kramer JR et al. (2011): Increasing prevalence of $\mathrm{HCC}$ and cirrhosis in patients with chronic hepatitis C virus infection. Gastroenterology, 140: 1182-1188.

16. Kudo M, Han KH, Kokudo $\mathbf{N}$ et al. (2010): Liver Cancer Working Group report. Jpn J Clin Oncol; $40: 1$.

17. Wu W, Yao DF, Yuan YM et al. (2006): Combined serum hepatoma-specific alpha-fetoprotein and circulating alpha-fetoprotein-mRNA in diagnosis of hepatocellular carcinoma. Hepatobiliary Pancreat Dis Int., 5:538-544.

18. Yu B, Yang X, Xu Y et al. (2009): Elevated expression of DKK1 is associated with cytoplasmic/nuclear betacatenin accumulation and poor prognosis in hepatocellular carcinomas. J Hepatol., 50:948-957.

19. Krupnik VE, Sharp JD, Jiang C et al. (1999): Functional and structural diversity of the human Dickkopf gene family. Gene, 238: 301-313.

20. Shen Q, Fan J, Yang XR et al. (2012): Serum DKK1 as a protein biomarker for the diagnosis of hepatocellular carcinoma: a large-scale, multicenter study. Lancet Oncol., 13:817-826.

21. Bakr H, Elfarargy $O$ and Elnaggar $A(2016)$ : Clinical significance of serum Dikkopf1 (DKK1) as a diagnostic marker for Hepatocellular Carcinoma. International Journal of Scientific Research, $5: 7$.

22. Yu B, Yang X, Xu Y et al. (2009): Elevated expression of DKK1 is associated with cytoplasmic/nuclear betacatenin accumulation and poor prognosis in hepatocellular carcinomas. J Hepatol., 50: 948-957.

23. Sharaf A, El-Said G, Khalifa N et al. (2016): Dickkopf1: As a Diagnostic and Prognostic Serum Marker for Hepatocellular Carcinoma. Afro-Egypt J Infect Endem Dis., 6(4):156-165.

24. Ge T, Shen Q, Wang N et al. (2015): Diagnostic values of alpha-fetoprotein, dickkopf-1, and osteopontin for hepatocellular carcinoma. Medoncol., 32(3): 59.

25. Kim SU, Park JH, Kim HS et al. (2015): Departments of 1 Internal Medicine, 3 Microbiology, 5 Laboratory Medicine, and 6 Nuclear Medicine, 2 Institute of Gastroenterology, 4 Institute for Immunology and Immunological Diseases, Yonsei University College of Medicine, Seoul; Yonsei Med J .,56(5):1296-1306. 